\title{
Effect of Christmas Melon (Laganaria Breviflorus) extract on toxigenic Mycoflora Isolated from Stored Unpolished Rice sold in major Markets in Abeokuta, Nigeria\#
}

\author{
Amina Badmos, ${ }^{1, a, *}$, Yetunde Mamood ${ }^{1, b}$ \\ ${ }^{1}$ Department of Microbiology, College of Bioscience, Federal University of Agriculture, Abeokuta, Nigeria \\ *Corresponding author

A R T I C L I N F O A B S T R A C T \\ ${ }^{\#}$ This study was presented as an online $\quad$ Study on toxigenic mycoflora and potential mitigation effect of Christmas Melon (Laganaria \\ presentation at the $2^{\text {nd }}$ International $\quad$ Breviflorus) extract in unpolished rice sold in Abeokuta Ogun state of Nigeria was carried out. \\ Journal of Agriculture - Food Science $\quad$ Unpolished rice gotten from markets in Abeokuta were aseptically transported to the laboratory, \\ \begin{tabular}{l|l} 
and Technology (TURJAF 2021) & serial dilution to reduce the fungal load was carried out and were plated on Potato Dextrose Agar
\end{tabular} \\ (PDA) and Methyl Red Dessicated Coconut Agar (MRDCA) respectively. Microscopy, \\ Research Article \\ macroscopy, toxigenicity test and inhibition studies with the peeled and unpeeled fruit of Laganaria \\ breviflorus fermented for seven days was carried out. Results reveal the predominance of \\ Aspergillus as the major genera, specifically, A. niger, A.flavus, A. parasiticus, A. fumigatus, A. \\ terreus, A. nidulans. Other fungi genera isolated include Penicillium, $F$ `usarium, Mucor, Alternaria \\ and Rhizopus. Of the 11 fungi genera isolated, 9 were toxigenic of which the zones of inhibition \\ of unpeeled whole fruit extract of Laganaria breviflorus range from $(3-28 \mathrm{~mm})$ where A. nidulans \\ shows the highest susceptibility to the whole fruit extract of Laganaria breviflorus while the zone \\ of inhibition of peeled fruit extract of Laganaria breviflorus ranges from $(3-22 \mathrm{~mm})$ where A. \\ parasiticus, Fusarium specie and P.chrysogenum showed the highest susceptibility. As the day \\ Keywords: \\ Christmas Melon \\ progresses the zone of inhibition becomes wider. Unpeeled LB extract exhibited more zones of \\ inhibition than the peeled LB extract. Laganaria breviflorus fruit extracts in the study demonstrates \\ Mycotoxins \\ Plant Extracts \\ Mycoflora \\ Food Safety \\ a potential in reducing toxigenic fungi, consequently a means to reducing mycotoxins in staple \\ foods in Nigeria.
}

badmosao@funaab.edu.ng (iD) https://orcid.org/0000-0002-3019-3566

\section{Introduction}

Rice (Oryza sativa) is the world's most extensively cultivated staple food crop after wheat which serves as main source of food to over $50 \%$ of the total world population and about 593 million tonnes (Mt) is produced annually globally (FAO, 2002). It is an important cereal plant belonging to the grass family Poaceae (Vaughan et al., 2003). Nigeria is ranked among the nine major riceimporting countries (Hynes, 2005) and it produces about 3.13 million tonnes on the average annually and also the highest producer in West Africa (Singh et al., 1997). The varieties produced in Nigeria are Oryza glaberrima 'Ofada, grown in Ofada town in the South west region of the country and new rice (NERICA), a hybrid of the $O$. sativa and $O$. glaberrima (WARDA, 2008). The importance of rice to the African population has allowed for its storage which is a means of ensuring an adequate, uniform and constant supply. It is also intended to protect it from harsh weather and various pests; preventing or delaying changes in nutritional value or loss of quality. Rice meant for commercial purposes is usually kept in large quantities in bags and barns and when stored in conditions such as high temperature and humidity, it encourages growth and contamination of fungi and production of toxins. Mycotoxigenic fungi contaminations of Food and feed are a serious health concern and have been established since the initiation of cultivation and storage of agricultural produce (Makhuvele et al., 2020). These toxigenic fungi majorly belong to the genera Aspergillus, Fusarium, Claviceps, Penicillium, Stachybotrys, and Altenaria, etc. They produce toxic secondary metabolites, which are not directly needed for their growth metabolism and development, known as mycotoxins. Although some of these secondary metabolites play a role in virulence, development and pathogenicity (Perincherry et al., 2019; Venkatesh and Keller, 2019). Propagation of fungi and the production of 
mycotoxins in food such as rice are consistently favoured by environmental factors peculiar to the tropical regions such as high humidity and temperature, where the fungi thrives perfectly. Of over the 400 mycotoxins that have been reported, the most studied are aflatoxins (AFs), ochratoxin A (OTA), Fusarium toxins, fumonisins (FBs), zearalenone (ZEA), trichothecenes (TCT) and deoxynivalenol (DON), which are capable of causing great health risks and economic losses (Alshannaq and $\mathrm{Yu}$,2017). Considering the deleterious effects of these fungal toxins, the mycotoxins have an enormous impact on diet safety and livelihood, as well as affect the competitiveness of agricultural production in sub-Saharan Africa (Udomkun et al., 2017). In spite of the rapid enlightenment of the problem, in a lot cases, the contamination with mycotoxins still exceeds the maximum acceptable limits and, thus, continues to threaten public health (Udomkun et al., 2017).

Numerous strategies to control and prevent mycotoxins in food and feed have been developed. These methods are grouped as chemical and micro-biological methods (Adebo et al., 2017; Adebiyi et al., 2019).

Plants and plant products such as essential oils, spices, herbs and crude extracts are discovered to be good biofungicides and nutraceuticals for controlling mycotoxicosis and related infections. They are considered as safer alternative means of bioagents for the control of fungi and mycotoxins in food and feed (Iram et al., 2016; Adebo et al., 2020; Prakash et al., 2020). Apart from the fact that they are affordable than other materials used for control, they also provide a combine approach as protectants of fungal/mycotoxin contamination and further stimulate pathways that elicit the natural defence systems in plant tissues (da Cruz Cabral et al., 2013; Alberts et al., 2019; Gacem et al., 2020; Meng et al., 2020). They contain various phytochemicals with pharmacological properties against various diseases. It is the aim of this study to test for potential antifungal properties of Laganaria breviflorus (Christmas melon) fruit as it has not be reported and since it has been used to control viral infections, it could be a potential remedy for aflatoxigenic fungi in food.

\section{Materials and Methods}

\section{Experimental Site of Research}

The experiment was undertaken at the Microbiology Department Laboratory, College of Biosciences, Federal University of Agriculture, Abeokuta, Ogun State, Nigeria.

\section{Collection of Rice Samples}

Ofada rice and Laganaria breviflorus fruits were purchased from markets in Abeokuta and transported to the laboratory in a sterile zip lock bag for further analysis.

\section{Serial Dilution}

Rice samples washed with distilled water was crushed in a sterile mortar and pestle. Nine test tubes were appropriately labeled, filled with $9 \mathrm{ml}$ of distilled water and sterilized in the autoclave. The distilled water was left to cool; $1 \mathrm{~g}$ of rice sample was weighed and added to the first test tube with sterile distilled water labeled $10^{-1}$. Using a pipette, $1 \mathrm{ml}$ of the mixture was transferred into the test tube labelled $10^{-2}$. This process was repeated for test tubes labelled $10^{-3}$ to $10^{-4}$. Dilutions $10^{-2}$ and $10^{-4}$ were used for culturing.

\section{Preparation of Culture Media}

All media used: Potato Dextrose Agar, Methyl Red Desiccated Coconut Agar, and Yeast Extract Agar were prepared according to manufacturer's instruction. The prepared media were sterilized in an autoclave at $121^{\circ} \mathrm{c}$ for 15 minutes the media was allowed to cool to about $45^{\circ} \mathrm{c}$ before pouring into petri dishes and Mc cartney bottles.

Formulation of Methyl Red Desiccated Coconut Agar

The method of (Atanda et al., 2005) was used in the preparation of (MRDCA):

200 grams of dessicated coconut was soaked in $1 \mathrm{~L}$ of hot distilled water for 30 minutes ( $\mathrm{pH}$ 4.77) blended aseptically in a Waring blender (Torrington, CT, USA) for 5 minutes and filtered through four layers of cheese cloth. Two percent of the filtrate was heated to boiling and cooled to about $50^{\circ} \mathrm{C}$. Small portion of methyl red was added to filtrate.

The media was then sterilized at $121^{\circ} \mathrm{C}$ for 15 minutes, cooled and poured uniformly $(15 \mathrm{ml})$ into sterile Petri dishes $(8.5 \mathrm{~cm})$ while being vigorously stirred with a sterile hockey stick. Care was taken to avoid trapping bubbles in the media.

\section{Inoculation and Incubation}

Pour and spread plate method were employed. The rice samples were aseptically processed and poured with the media in the petri dish by swirling the petri dish for pour plate method. The prepared media were poured into the petri dishes and allowed to solidify. After solidification, $0.1 \mathrm{ml}$ of each sample was spread on the solidified media in the petri dishes for spread plate method. All the plate were labelled appropriately and incubated at room temperature for 72 hours. Distinct colonies were isolated and sub cultured until pure colonies were obtained. The pure cultures were stored on PDA slants for characterization and identification.

\section{Identification and Characterization of Fungi Isolates}

Isolates were identified macroscopically through: colour, texture, elevation and pigmentation also microscopically using lactophenol cotton blue mount.

\section{Microscopic Examination}

An inoculating loop was used to pick small portion of the isolate and immersed in lactophenol cotton blue and the organism was carefully teased into strain. After teasing, the mixture was covered with coverslip and the fungus was examined microscopically under a microscope using $\times 40$ objective lens. The yeast isolates were stained using gram staining procedure and examined under the microscope.

\section{Toxigenicity Test of Fungal Isolates}

The Aspergillus isolates were cultured on Methyl Red Desiccated Coconut Agar Medium and incubated in a dark cupboard at room temperature for three days. After incubation, the growths on the plates were exposed to ultraviolet light for 3 hours at 360nm to observe production of fluorescence by the isolates. The isolates that fluorescence was considered toxigenic. (Atanda et al., 2011). 
Extraction Procedure of Laganaria Breviflorus (Christmas Melon) Fruits

Laganaria Breviflorus was washed thoroughly. The fruit was peeled and sliced into eight conical flasks while another set of the fruits were left unpeeled fruits and steeped in water in also eight conical flasks. Distilled water was added to the sliced portion with a ratio of 1:2. The conical flasks was covered tightly with Foil and placed in a dark room for fermentation to take place for seven days. The fermented fruits (Peeled and Unpeeled) were blended and filtered repeatedly from day 0 to day 8 using What man No.1 filter paper.

\section{Inhibitory Process of Laganaria Breviflorus}

The toxigenic strains were inoculated on Yeast Extract Agar medium in order to preserve the strains. The isolates in the Yeast Extract Agar were cultured on freshly prepared and sterilized PDA medium using pour plate method and allowed to solidify. After solidification, the plates were properly punctured using sterile metal cork borer, the peeled and unpeeled fruit extracts of Laganaria breviflorus was introduced into the holes and labelled appropriately. Control plates were maintained without addition of the extracts. All the plates were incubated at room temperature for 72 hours under sterile conditions. The zones of inhibition were measured around each well. The ones that exhibited the highest zone of inhibition were subjected to Gas Chromatography Mass Spectrophometry (GC-MS).

\section{Results}

\section{Isolation and Characterization of Fungal Isolates From Ofada Rice}

A total number of 11 isolates were purified from Ofada rice gotten from Lafenwa market, Abeokuta Ogun state. Fungi genera that include Aspergillus, Penicillium, Fusarium, Neurospora and yeast were isolated. The microscopic and macroecopic view of the isolates are shown in (Table 1 and 2)

Table 1. Macroscopic Characteristics of Fungal Isolates

\begin{tabular}{|c|c|c|c|c|}
\hline Isolates & Surface Color & Reverse Side of the Agar & Elevations & Growth \\
\hline Aspergillus niger & $\begin{array}{l}\text { Dark brown to } \\
\text { Black }\end{array}$ & White to yellow & Umbonate & Rapid \\
\hline Aspergillus flavus & $\begin{array}{l}\text { Yellow/greyish } \\
\text { green }\end{array}$ & Colourless to yellow & Umbonate & Moderate to rapid \\
\hline Aspergillus parasiticus & Dark green & Orange yellow & Convex & Fast \\
\hline Aspergillus fumigatus & Blue green & White to $\tan$ & Umbonate & Rapid \\
\hline Aspergillus terreus & $\begin{array}{l}\text { Pinkish cinnamon } \\
\text { to deeper with age }\end{array}$ & $\begin{array}{l}\text { Pale to bright yellow to } \\
\text { deep brown }\end{array}$ & Umbonate & Moderate to rapid \\
\hline Aspergillus nidulans & Dark cress green & $\begin{array}{l}\text { Purplish red, brownish } \\
\text { dark with age }\end{array}$ & Umbonate & Slow to moderate \\
\hline Penicillium chrysogenum & Dark lemon green & Yellow white & Flat & Moderate \\
\hline Neurospora crassa & Royal orange & Light brown & Raised & Fast \\
\hline Mucor sp. & Pale brown & Brown & Curled, Raised & Fast \\
\hline Fusarium sp. & Magenta pink & Magenta red turning violet & Raised & Moderate \\
\hline Saccharomyces sp. & Creamy to white & White to light yellow & $\begin{array}{l}\text { Flat, smooth, } \\
\text { moist, dull }\end{array}$ & Moderate \\
\hline
\end{tabular}

Table 2. Microscopic characteristics of fungal isolates

\begin{tabular}{|c|c|c|c|c|}
\hline Isolate & Colour of spore & Type of spore & Septation & Conidia shape \\
\hline Aspergillus niger & $\begin{array}{l}\text { Deep brown- } \\
\text { black }\end{array}$ & Conidiospore & Septate & $\begin{array}{l}\text { Globules to subglobulus } \\
\text { and very rough }\end{array}$ \\
\hline Aspergillus flavus & Greenish yellow & Conidiospore & Septate & Spherical \\
\hline A. Parasiticus & Pink & Conidiospore & Septate & $\begin{array}{l}\text { Rough, thick wall and } \\
\text { spherical }\end{array}$ \\
\hline Aspergillus terreus & Tan to brown & Conidiospore & Septate & $\begin{array}{l}\text { Biseriate, compact and } \\
\text { densely columnar conidial } \\
\text { heads }\end{array}$ \\
\hline A. Nidulans & Dark green & Conidiospore & Septate & $\begin{array}{l}\text { Conidial head are } \\
\text { Columnar,vesicles are } \\
\text { hemispherical Conidia are } \\
\text { globose and rough }\end{array}$ \\
\hline P. chrysogenum & $\begin{array}{l}\text { Blue to blue } \\
\text { green }\end{array}$ & Conidiospore & Septate & Flask shaped \\
\hline Neurospora crassa & Pinkish orange & Ascospore & Septate & $\begin{array}{l}\text { Longitudinal striations } \\
\text { resembling nerve axons }\end{array}$ \\
\hline Mucor sp. & $\begin{array}{l}\text { White to greenish } \\
\text { brown }\end{array}$ & Sporangiospore & $\begin{array}{l}\text { Non } \\
\text { septate }\end{array}$ & Globose shaped \\
\hline Fusarium sp. & Brown & chlamydiospore & Septate & Circular \\
\hline
\end{tabular}


Determination of Toxigenic Fungi Isolates on Methyl Red Dessicated Coconut Agar (MRDCA)

The isolates that tested positive for toxin production of the fungi isolated are represented in (Table 3). Aspergillus niger, Aspergillus flavus, Aspergillus fumigatus, Aspergillus parasiticus, Penicillium chrysogenum and Fusarium sp. were those that fluorescence on MRDCA indicating toxin production.

Antifungal Activity of Unpeeled Laganaria Breviflorus Fruits Extracts (Zone Of Inhibition in Mm)

Inhibitory effects of unpeeled Laganaria Breviflorus on the toxigenic isolates monitored for 7days is shown on (Table 4) inhibition occurred significantly on the seventh day extract against all isolates and less significant on the first to the sixth day. A. nidulans was the most susceptible organism to the seventh day extract. Figure 1 shows the degree of inhibition of all the organisms by the extracts as the day progresses.

\section{Antifungal Activity of peeled Laganaria Breviflorus} Fruits Extracts (Zone Of Inhibition in Mm)

Inhibitory effects of peeled Laganaria Breviflorus on the toxigenic isolates monitored for 7days is shown on (Table 5) inhibition occurred significantly on the seventh day extract on all isolates and less significant on the first to the sixth day. A.parasiticus, penicilium sp. and fusarium $s p$. were most susceptible organisms to the seventh day extract. Figure 2 shows the degree of inhibition of all the organisms by the extracts as the day progresses.

Table 3. Toxigenic fungi isolates on methyl red dessicated coconut agar(mrdca)

\begin{tabular}{l|c}
\hline \multicolumn{1}{c|}{ Isolates } & Toxigenicity \\
\hline Aspergillus niger & Positive \\
Aspergillus flavus & Positive \\
Aspergillus parasiticus & Positive \\
Aspergillus fumigatus & Positive \\
Aspergillus nidulans & Positive \\
Penicillium chrysogenum & Positive \\
Neurospora crassa & Negative \\
Mucor sp. & Negative \\
Fusarium sp. & Positive \\
\hline
\end{tabular}

Table 4. Antifungal Activity of Unpeeled Laganaria Breviflorus Fruits Extracts (Zone Of Inhibition in mm)

\begin{tabular}{l|llllllll}
\hline $\begin{array}{c}\text { Toxigenic } \\
\text { Fungi Isolates }\end{array}$ & Day 0 & Day 1 & Day 2 & Day 3 & Day 4 & Day 5 & Day 6 & Day 7 \\
\hline A. niger & 0 & 03 & 05 & 08 & 10 & 13 & 16 & 19 \\
A. flavus & 0 & 07 & 13 & 15 & 16 & 19 & 22 & 26 \\
A.parasiticus & 0 & 05 & 09 & 10 & 13 & 16 & 18 & 22 \\
A. fumigatus & 0 & 06 & 10 & 15 & 17 & 19 & 20 & 22 \\
A. nidulans & 0 & 18 & 20 & 21 & 23 & 25 & 25 & 28 \\
P. chrysogenum & 0 & 08 & 10 & 13 & 15 & 17 & 19 & 23 \\
Mucor sp. & 0 & 07 & 09 & 11 & 13 & 15 & 18 & 20 \\
Fusarium sp. & 0 & 06 & 08 & 10 & 13 & 16 & 18 & 21 \\
A. terreus & 0 & 09 & 13 & 15 & 17 & 18 & 20 & 21 \\
\hline
\end{tabular}

Suceptible: $\geq 19 \mathrm{~mm}$, Intermediate: $15-18 \mathrm{~mm}$ and Resistant: $\leq 14 \mathrm{~mm}$

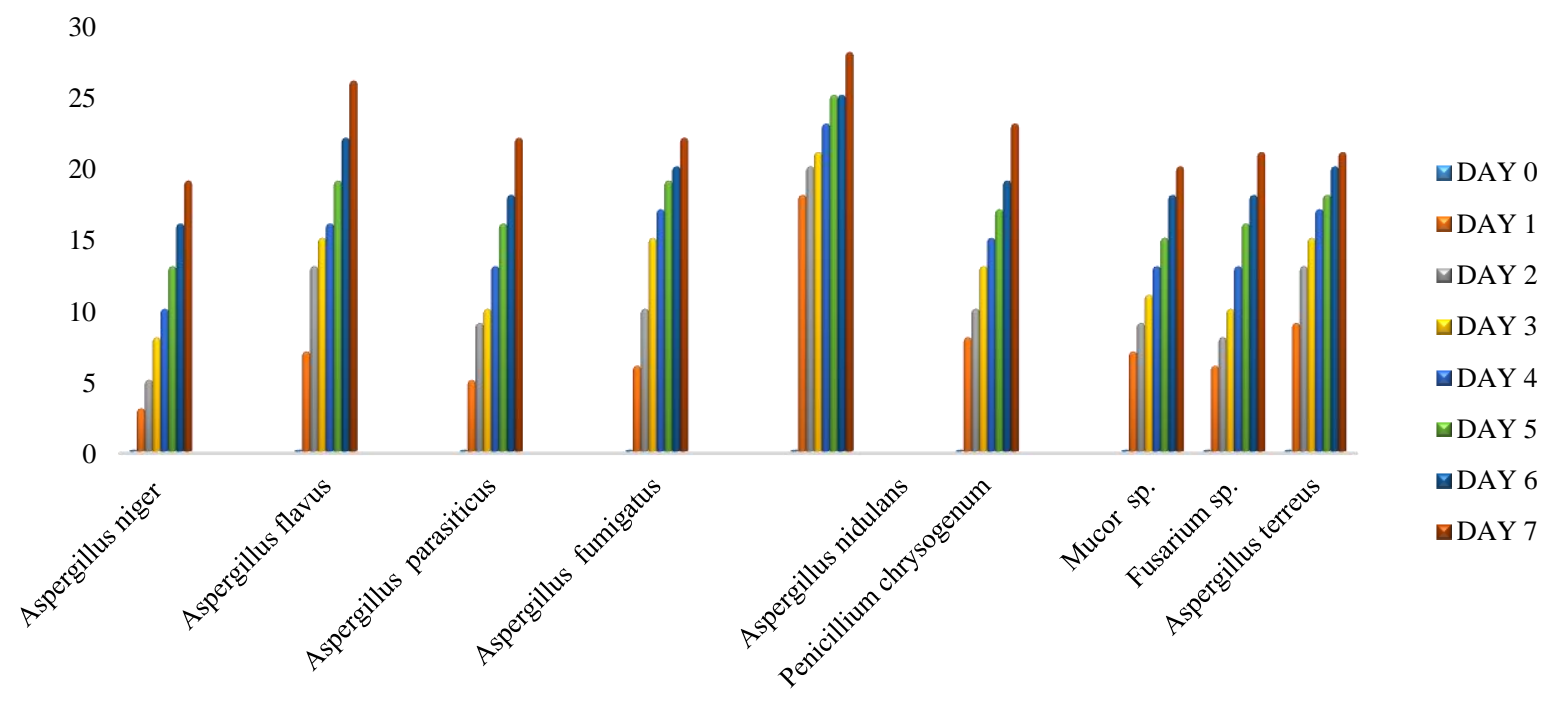

Figure 1. Zone of inhibition of unpeeled LB whole fruit extract on Fungal Isolate 
Table 5. Antifungal Activity of Peeled Laganaria Breviflorus Whole Fruits Extracts (Zone Of Inhibition $\mathrm{mm}$ )

\begin{tabular}{l|cccccccc}
\hline $\begin{array}{c}\text { Toxigenic Fungi } \\
\text { Isolates }\end{array}$ & Day 0 & Day 1 & Day 2 & Day 3 & Day 4 & Day 5 & Day 6 & Day 7 \\
\hline A. niger & 0 & 03 & 05 & 08 & 10 & 13 & 15 & 18 \\
A. flavus & 0 & 04 & 08 & 10 & 13 & 16 & 19 & 20 \\
A. parasiticus & 0 & 05 & 08 & 10 & 13 & 15 & 18 & 22 \\
A. fumigatus & 0 & 07 & 11 & 13 & 15 & 16 & 18 & 20 \\
A. Nidulans & 0 & 05 & 10 & 12 & 13 & 15 & 16 & 18 \\
P.chrysogenum & 0 & 07 & 10 & 12 & 15 & 18 & 20 & 22 \\
Mucor sp. & 0 & 10 & 11 & 13 & 15 & 17 & 18 & 20 \\
Fusarium sp. & 0 & 0 & 10 & 12 & 15 & 17 & 20 & 22 \\
A. terreus & 0 & 08 & 13 & 15 & 17 & 18 & 20 & 21 \\
\hline
\end{tabular}

Suceptible: $\geq 19 \mathrm{~mm}$, Intermediate: $15-18 \mathrm{~mm}$ and Resistant: $\leq 14 \mathrm{~mm}$

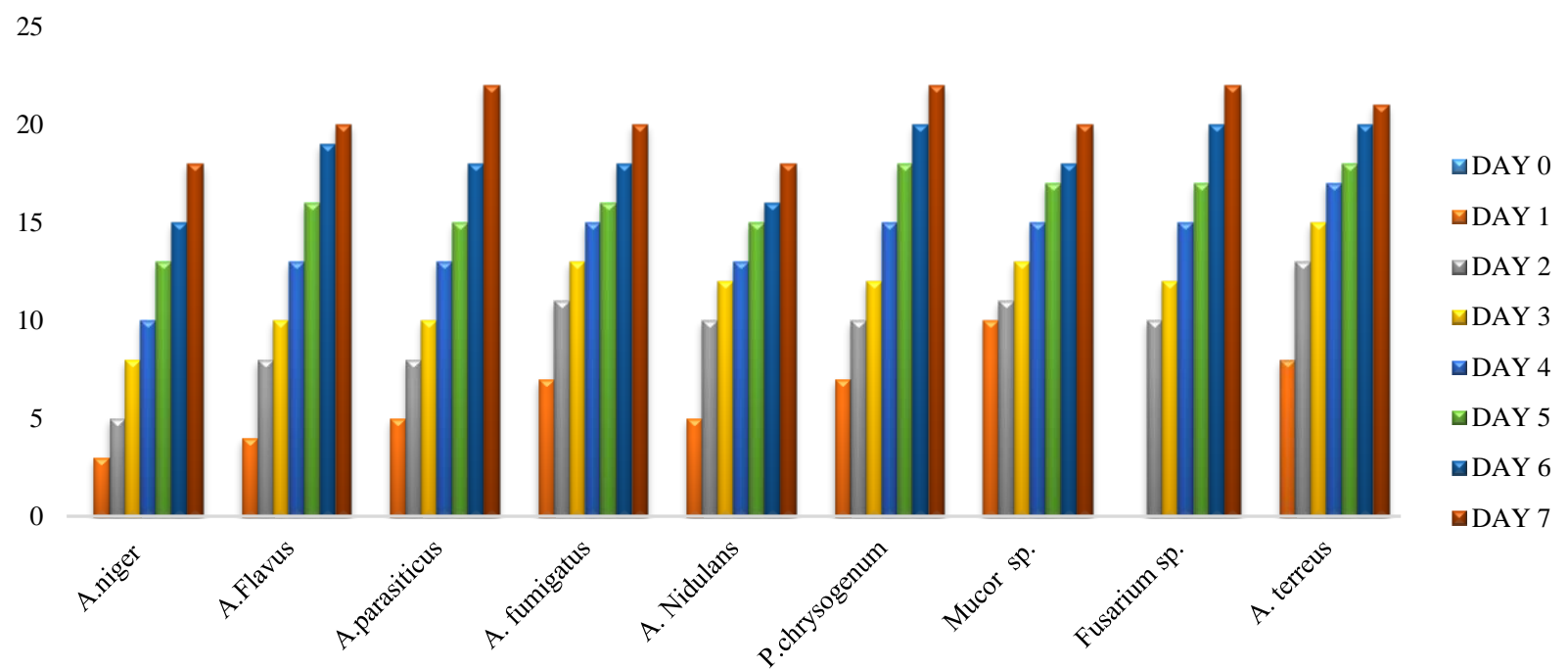

Figure 2. Zone of Inhibition of Peeled Lb Whole Fruit Extracts on Fungal Isolates

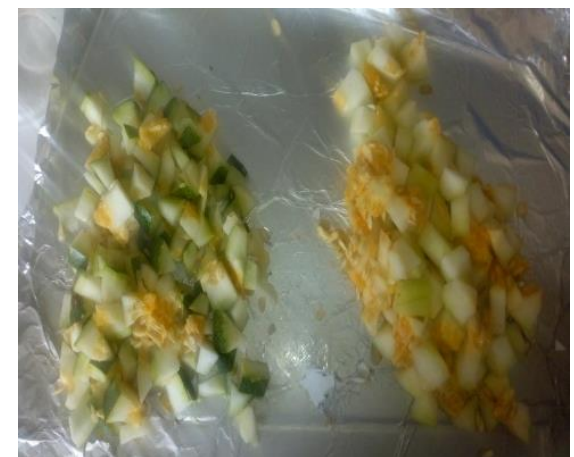

A

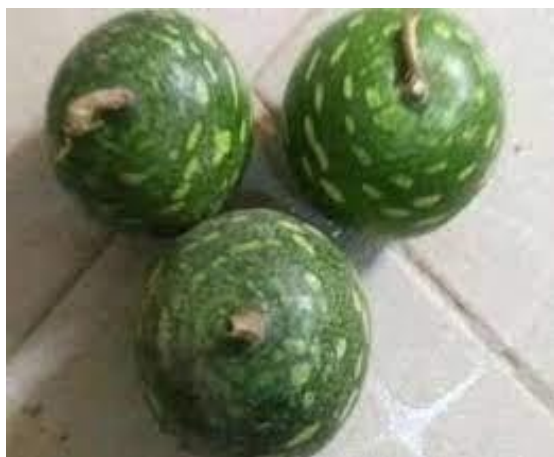

B

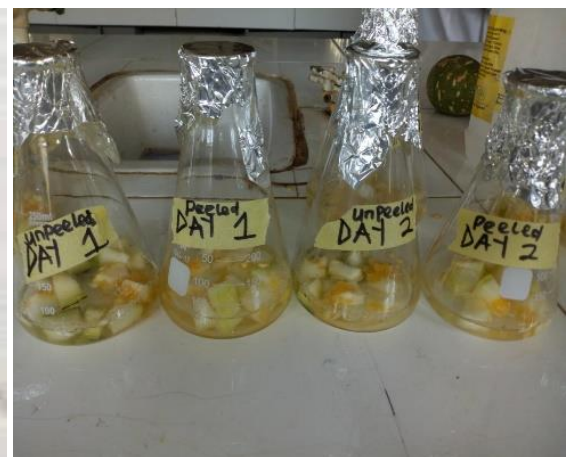

$\mathrm{C}$

Figure 3. Plates showing Laganaria Breviflorus Fruits

A Whole Laganaria Breviflorus fruit, B Choped Laganaria Breviflorus fruit, C Laganaria Breviflorus steeped in distilled water for 7 days

\section{Discussion}

Some of the fungal genera found in this study isolated from rice gotten from markets in Abeokuta have also been reported in rice cultivated in Niger State (Makun et al., 2007) and also by Uraguchi Yamazaki, (1978) also described the fungi such as Aspergillus, fusarium and penicillium as mycoflora of Japanese rice. The fungal isolates gotten from ofada rice also corresponds with study of (Kumar et al., 2017) who reported that Aflatoxins are synthesized by many fungi spp. Including Aspergillus, Penicillium, Fusarium, and Alternaria but Aspergillus flavus and Aspergillus parasiticus are known to produce the most toxigenic strains of aflatoxins. He also stated that the toxigenic isolates in staple food shows that eating ofada rice contaminated with mycotoxins is a potent hepato carcinogenic, mutagenic, teratogenic and it suppresses the immune system

Plants, according to (Madrigal-Santillan et al., 2010; Anjorin et al., 2013) posseses antimutagens, antimicrobial, antioxidants or anticar- cinogens capable of mitigating the toxic and genotoxic effects of mycotoxins. Antioxidants protect the cell membranes and macromolecules by capturing free radicals (Wu et al., 2017a). Plant extracts and their compounds also act by inducing xenobiotic detoxification and biotransformation pathways (Gross- 
Steinmeyer and Eaton, 2012; Wu et al., 2017b) capable of inhibiting enzymes that activate Phase I carcinogens as well as induce enzymes for Phase II detoxification (Galvano et al., 2001; Wu et al., 2017b). Antifungal activity of Laganaria breviflorus fruit extracts on the fungal species isolated from this study has proven its efficacy as a biofungicide. Antifungal and antimycotoxigenic activities of herbal plants with potential antioxidant properties were investigated against fungal strains that are phytopathogenic, i.e. Fusarium verticillioides, A. flavus and A. ochraceus.

A study by Abdel-Fattah et al., (2018) reported the antioxidant, antifungal and anti-mycotoxigenic potentials of wild stevia extracts against A. flavus, A. ochraceus, $A$. niger, and $F$. moniliforme. Furthermore, essential oils have been found to effectively modulate the growth of mycotoxigenic fungi such as A. favus, A. oryzae, A. niger, Alternaria alternata, $F$. moniliforme, $F$. graminearum, Penicillium citrinum and $P$. viridicatum, etc., and their asso- ciated mycotoxins (da Cruz Cabral et al., 2013; Prakash et al., 2015). Laganaria breviflorus was most inhibitor after steeping it for 7 days this might have been due to fermentation process that might have occulted hence the inhibition. To the best of our knowledge the organisms involved during fermentation process for seven days might be responsible or the active components present in the LB whole fruit extracts.

So far, no study has revealed the use of Laganaria breviflorus in solving the problem of aflatoxins in staple foods such as ofada rice; this is the first of its kind. Although it is widely used in folklore medicine in West Africa as antibacterial and antiviral herbal remedies.

\section{Conclusion}

Quite a number of studies have reported the use of plants and plants products for mitigation of aflatoxigenic fungi in staple foods but none has reported the use of Laganaria breviflorus (tagiri), and since Laganaria breviflorus (tagiri) has been used to control viral infections, This study has ascertained that the toxigenic fungi isolated from rice were susceptible to the whole fruit of Laganaria breviflorus extract . Therefore, the whole fruit of Laganaria breviflorus extracts showed potential in the inhibitory effect of toxigenic fungal isolates in ofada rice. However, the unpeeled extracts of Laganaria breviflorus whole fruits showed higher potential in the inhibitory effect of toxigenic fungal isolates from rice.

\section{References}

Adebiyi JA, Kayitesi E, Adebo OA, Changwa R, Njobeh PB. 2019. Food fermentation and mycotoxin detoxification: an African perspective. Food Control 106

Adebo OA, Moleleko T, Makhuvele R, Adebiyi JA, Oyedeji AB, Gbashi S, Adefisoye MA, Ogundele OM, Njobeh PB. 2020. A review on novel non-thermal food processing techniques for mycotoxin reduction. International Journal of Food Science and Technology.

Adebo OA, Njobeh PB, Gbashi S, Nwinyi OC, Mavumengwana, V. 2017. Review on microbial degradation of aflatoxins. Critical Review of Food Science and Nutrition. 57, 32083217.
Alberts J, Rheeder J, Gelderblom W, Shephard G, Burger H. 2019. Rural subsistence maize farming in South Africa: risk assessment and intervention models for reduction of exposure to Fumonisin mycotoxins. Toxins 11, 334.

Alshannaq A, Yu JH. 2017 Occurrence, Toxicity, and Analysis of Major Mycotoxins in Food. International Journal of Environmental Public Health, 14, 632.

Atanda OO, Akpan I, Rati ER, Ozoje M. 2005. Palm kernel; a potential substrate for rapid detection of aflatoxins in agricultural commodities. African Journal of Biotechnology

Bentivenga G, Spina A. Ammar K. Allegra M. Cacciola SO. 2021. Screening of Durum Wheat (Triticum turgidum L. subsp. durum (Desf.) Husn.) Italian Cultivars for Susceptibility to Fusarium Head Blight Incited by Fusarium graminearum. Plants, 10, 68.

Da Cruz Cabral L, Fern andez Pinto V. Patriarca A. 2013. Application of plant derived compounds to control fungal spoilage and mycotoxin production in foods. International Journal of Food Microbiology. 166, 1-14.

FAO. 2002. Proceedings of the 20th Session of the International Rice Commission in Bangkok Corporate Document Repository.5:1029-1033

Fung F, Clark RF. 2004. Health Effects of Mycotoxins: A Toxicological Overview. Journal of Toxicology. Clinical Toxicology. 42, 217-234.

Gacem MA, Gacem H, Telli A, Khelil AO. 2020. Mycotoxins: decontamination and nanocontrol methods. In: Nanomycotoxicology. Elsevier, pp. 189-196.

Hynes E. 2005. Rice," MicrosoftÂA EncartaÂA Online Encyclopedia http://encarta.msn.com,

Iram W, Anjum T, Iqbal M, Ghaffar A, Abbas M. 2016. Structural elucidation and toxicity assessment of degraded products of aflatoxin B1 and B2 by aqueous extracts of Trachyspermum ammi. Frontier Microbiolology 7.

Madrigal-Santillan E, Morales-Gonzalez JA, Vargas-Mendoza N, Reyes-Ramirez P, Cruz-Jaime S, Sumaya-Martinez T, PerezPasten R, Madrigal-Bujaidar E. 2010. Antigenotoxic studies of different substances to reduce the DNA damage induced by aflatoxin B1 and ochratoxin A. Toxins 2, 738-757.

Makhuvele R, Naidu K. Gbashi S. Thipe VC. Adebo OA, Njobeh PB. 2020. The use of plant extracts and their phytochemicals for control of toxigenic fungi and mycotoxins. Helios, 6, E05291

Meng D, Garba B, Ren Y, Yao M., Xia X. Li M. Wang Y. 2020. Antifungal activity of chitosan against Aspergillus ochraceus and its possible mechanisms of action. Int. J. Biol. Macromolecule. 158, 1063-1070.

Perincherry L, Lalak-Kanczugowska J, Stepien L. 2019. Fusarium-producedmycotoxins in plant-pathogen interactions. Toxins 11.

Prakash B. Kumar A, Singh PP, Songachan LS, 2020. Antimicrobial and antioxidant properties of phytochemicals: current status and future perspective. Functional and Preservative Properties of Phytochemicals. Elsevier, pp. 145.

Prakash B, Kumar A, Singh PP, Songachan LS, 2020. Antimicrobial and antioxidant properties of phytochemicals: current status and future perspective. Functional and Preservative Properties of Phytochemicals. Elsevier, pp. 145.

Singh BN, Fagade S, Ukwungwu MN, Williams C, Jagtap SS. Oladimeji O, Efisue A. Okhidievbie O. 1997. Rice growing environments and biophysical constraints in different agroecological zones of Nigeria. Journal of Meterology (1), $35-44$

Udomkun P, Wiredu AN, Nagle M, Bandyopadhyay R, Müller J, Vanlauwe B. 2017. Mycotoxins in Sub-Saharan Africa: Present situation, socio-economic impact, awareness, and outlook. Food Control, 72, 110-122. 
Vaughan DA, Morishima H, Kadowaki K. 2003. Diversity in the Oryza genusCurrent Opinion in Plant Biology, 6,139-146

Venkatesh N, Keller NP. 2019. Mycotoxin in conversation with bacteria and fungi. Frontial Microbiology, 10.

Wild CP, Gong YY. 2010. Mycotoxins and human disease: A largely ignored global health issue. Carcinogenesis, 31, 7182.
Wu JC, Lai CS, Tsai ML, Ho T, Wang YJ. Pan MH, 2017b. Chemopreventative effect of natural dietary compounds on xenobiotic-induced toxicity. Journal of Food Drug Analysis 25, 176-186.

Wu Q, Wang X, Nepovimova E, Wang Y, Yang H, Li L, Zhang X, Kuca K. 2017a. Antioxidant agents against trichothecenes: new hints for oxidative stress treatment. Oncotarget 8, 110708-110726. 